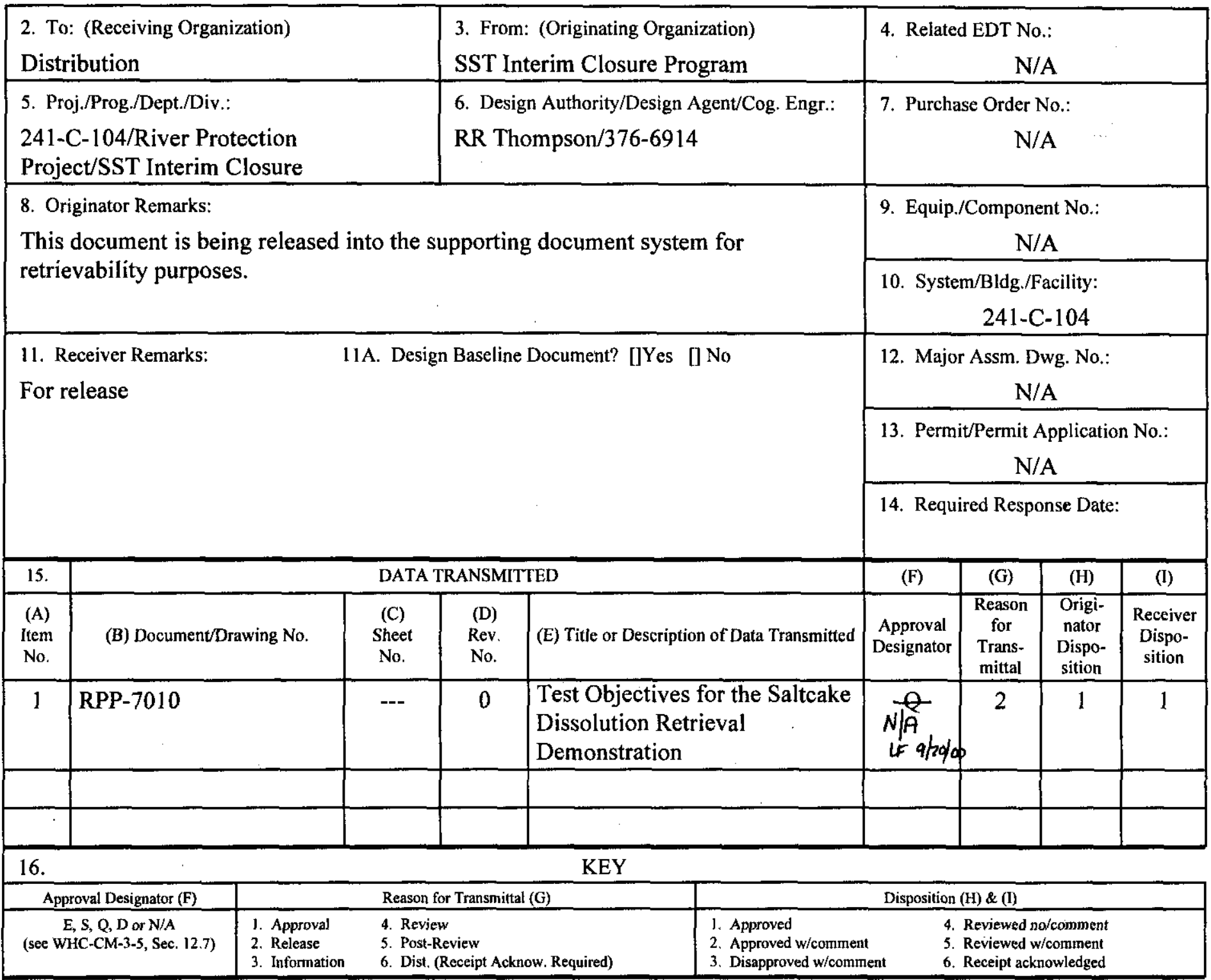

SIGNATURE/DISTRIBUTION

(See Approval Designator for required signatures)

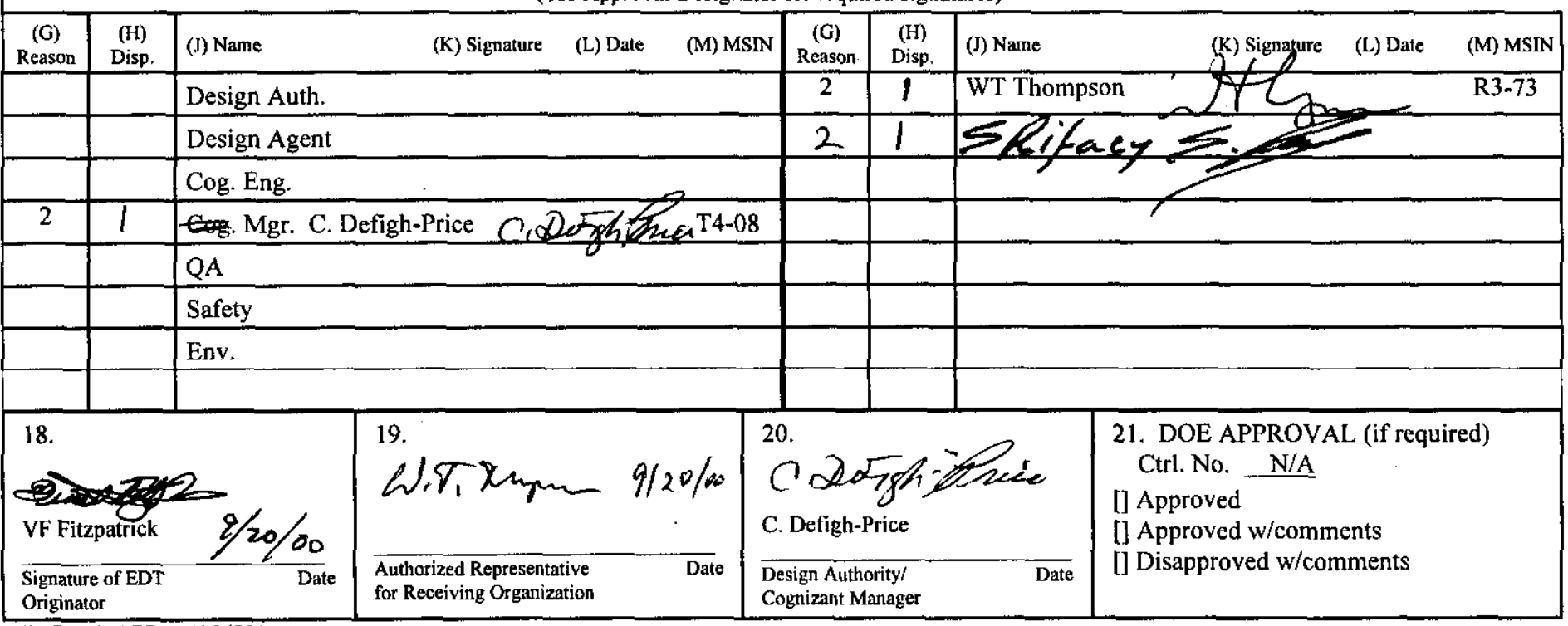




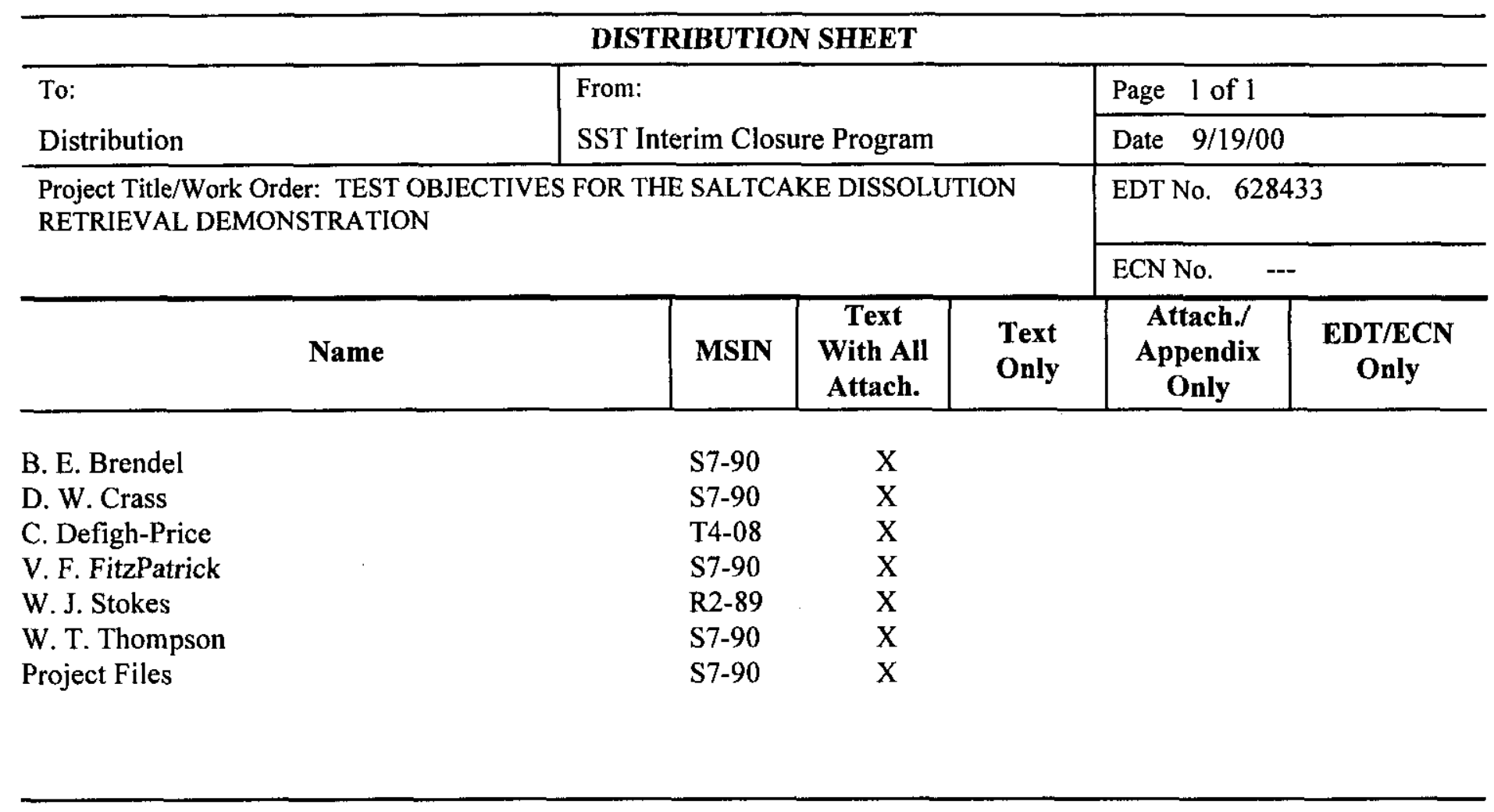




\section{TEST OBJECTIVES FOR THE SALTCAKE DISSOLUTION RETRIEVAL DEMONSTRATION}

C. Defigh-Price CH2M Hill Hanford Group, Inc.

Richland, WA 99352

U.S. Department of Energy Contract DE-AC06-99RL-14047

EDT/ECN: $628433 \quad$ UC: 721

Org Code: 6 N100 Charge Code: 113029/BA31

B\&R Code: Total Pages: 17

Key Words: Tanks, Saltcake, Dissolution, Retrieval

Abstract:

TRADEMARK DISCLAIMER. Reference herein to any specific commercial product, process, or service by trade name, trademark, manufacturer, or otherwise, does not necessarily constitute or imply its endorsement, recommendation, or favoring by the United States Government or any agency thereof or its contractors or subcontractors.

Printed in the United States of America. To obtain copies of this document, contact: Document Control Services, P.O. Box 950, Mailstop H6-08, Richland WA 99352, Phone (509) 372-2420; Fax (509) 376-4989.
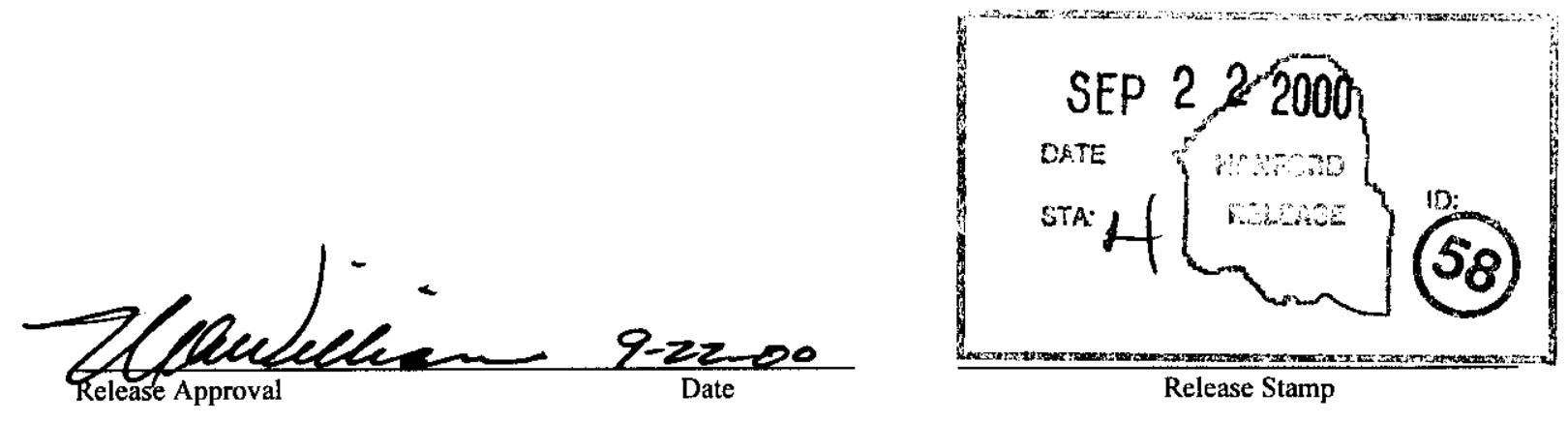

APPROVED FOR PUBLIC RELEASE 
RPP-7010

Revision 0

\section{TEST OBJECTIVES FOR THE SALTCAKE DISSOLUTION RETRIEVAL DEMONSTRATION}

Prepared for the U.S. Department of Energy

Assistant Secretary for Environmental Management

\section{CH2MHILL}

Hanford Group, Inc.

Richland, Washington 
RPP-7010

Revision 0

\section{TEST OBJECTIVES FOR THE SALTCAKE DISSOLUTION \\ RETRIEVAL DEMONSTRATION}

Prepared by:

W. T. Thompson

CH2M HILLL Hanford Group, Inc.

Richland, Washington

Date Published

September 2000

Prepared for the U.S. Department of Energy

Assistant Secretary for Environmental Management

\section{CH2MHILL}

Hanford Group, Inc.

P.O. Box 1500

Richland, Washington

Contractor for the U.S. Department of Energy

Office of River Protection under Contract DE-AC06-99RL14047

Approved for Public Release; Further Dissemination Unlimited 


\section{LEGAL DISCLAIMER}

This report was prepared as an account of work sponsored by an agency of the United States Government. Neither the United States Government nor any agency thereof, nor any of their employees, nor any of their contractors, subcontractors or their employees, makes any warranty, express or implied, or assumes any legal liability or responsibility for the accuracy, completeness, or any third party's use or the results of such use of any information, apparatus, product, or process disclosed, or represents that its use would not infringe privately owned rights. Reference herein to any specific commercial product, process, or service by trade name, trademark, manufacturer, or otherwise, does not necessarily constitute or imply its endorsement, recommendation, or favoring by the United States Government or any agency thereof or its contractors or subcontractors. The views and opinions of authors expressed herein do not necessarily state or reflect those of the United States Government or any agency thereof.

This report has been reproduced from the best available copy.

Available in paper copy and microfiche.

Available electronically at http:/www.doe.gov/bridge. Available for a processing fee to the U.S. Department of Energy and its contractors, in paper, from:

U.S. Department of Energy

Office of Scientific and Technical Information P.O. Box 62

Oak Ridge, TN 37831-0062

phone: $865-576-8401$

fax: 865-576-5728

email: reports@adonis.osti.gov(423) 576-8401

Available for sale to the public, in paper, from:

U.S. Department of Commerce

National Technical Information Service

5285 Port Royal Road

Springfield, VA 22161

Phone: 800-553-6847

fax: 703-605-6900

email: orders@ ntis.fedworld.gov

online ordering:

http://www.ntis.gov/ordering.htm 
RPP-7010

Rev. 0

\section{Test Objectives}

\section{For The Saltcake Dissolution Retrieval}

\section{Demonstration}

September 15, 2000

Approvals:

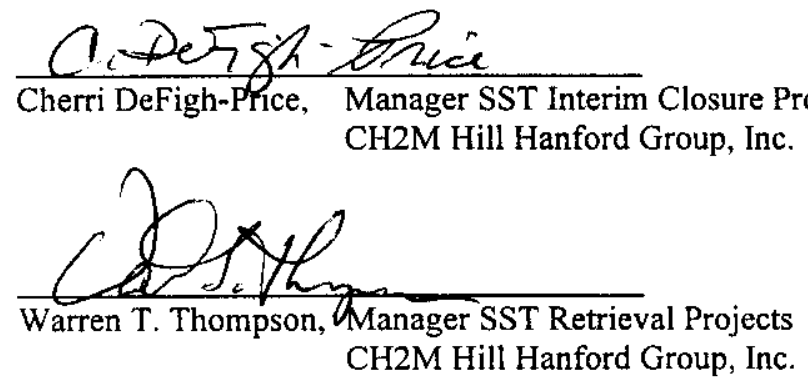




\section{Table of Contents}

\begin{tabular}{|c|c|}
\hline 1.1 & 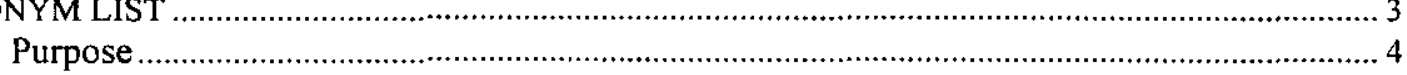 \\
\hline 1.2 & Background.. \\
\hline 1.3 & Milestones...................................................... \\
\hline 2.0 & 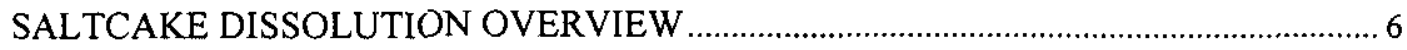 \\
\hline 3.0 & SALTCAKE DISSOLUTION DEPLOYMENT HOT TEST. \\
\hline 3.1 & 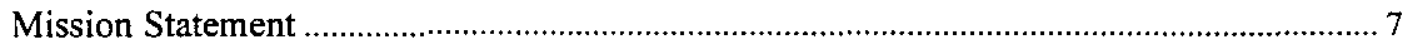 \\
\hline 3.2 & - \\
\hline 3.3 & Test Description \\
\hline 3.4 & Scope \\
\hline 4.0 & TEST GOALS \\
\hline 5.0 & TEST OBJECTIVES ............ \\
\hline 5.1 & 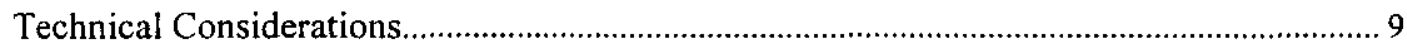 \\
\hline 5.2 & 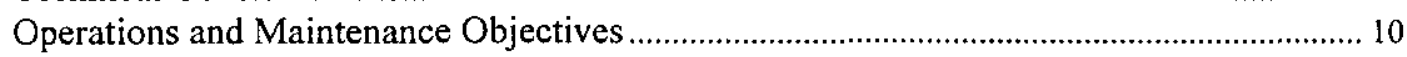 \\
\hline 5.3 & Retrieval System Objectives \\
\hline 5.4 & 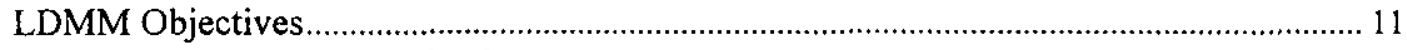 \\
\hline 5.5 & 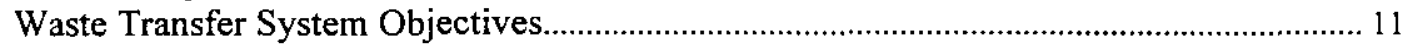 \\
\hline 5.6 & 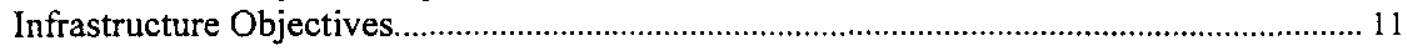 \\
\hline 5.7 & Cost, Planning and Schedule Objectives \\
\hline 6.0 & ASSUMPTIONS/CONSTRAINTS \\
\hline 7.0 & REFERENCES \\
\hline
\end{tabular}




\title{
ACRONYM LIST
}

\author{
AB Authorization Basis \\ BBI Best Basis Inventory \\ CHG CH2M Hill Hanford Group, Inc. \\ DOE U.S. Department of Energy \\ DST Double Shell Tanks \\ ESP Environmental Simulation Program \\ GPM Gallons Per Minute \\ IS Interim Stabilization \\ IWRS Integrated Waste Retrieval System \\ Kgal Kilo-gallons, one thousand gallons \\ LDMM Leak Detection, Monitoring and Mitigation \\ LVDG Low Volume Density Gradient \\ PPS Past Practice Sluicing \\ RPE Retrieval Performance Evaluation \\ RPP River Protection Project \\ SST Single Shell Tanks \\ TPA Tri-Party Agreement \\ TWRS Tank Waste Remediation System \\ UST Underground Storage Tank \\ WFD Waste Feed Delivery \\ WRS Waste Retrieval System \\ WTF Waste Treatment Facility \\ WTS Waste Transfer System
}




\section{TEST OBJECTIVES FOR THE SALTCAKE DISSOLUTION RETRIEVAL DEMONSTRATION}

\subsection{INTRODUCTION}

\section{$1.1 \quad$ Purpose}

This document describes the objectives the Saltcake Dissolution Retrieval Demonstration. The near term strategy for single-shell tank waste retrieval activities has shifted from focusing on maximizing the number of tanks entered for retrieval (regardless of waste volume or content) to a focus on scheduling the retrieval of wastes from those single-shell tanks with a high volume of contaminants of concern. These contaminants are defined as mobile, long-lived radionuclides that have a potential of reaching the groundwater and the Columbia River. This strategy also focuses on the performance of key retrieval technology demonstrations, including the Saltcake Dissolution Retrieval Demonstration, in a variety of waste forms and tank farm locations to establish a technical basis for future work. The work scope will also focus on the performance of risk assessment, retrieval performance evaluations (RPE) and incorporating vadose zone characterization data on a tank-by-tank basis, and on updating tank farm closure/post closure work plans.

The deployment of a retrieval technology other than Past-Practice Sluicing (PPS) allows determination of limits of technical capabilities, as well as, providing a solid planning basis for future SST retrievals. This saltcake dissolution technology deployment test will determine if saltcake dissolution is a viable retrieval option for SST retrieval. CH2M Hill Hanford Group $(\mathrm{CHG})$ recognizes the SST retrieval mission is key to the success of the River protection Project (RPP) and the overall completion of the Hanford Site cleanup.

The objectives outlined in this document will be incorporated into and used to develop the test and evaluation plan for saltcake dissolution retrievals. The test and evaluation plan will be developed in fiscal year 2001.

\subsection{Background}

The Hanford Site was established in 1943 as part of the Manhattan Project with the primary function of producing weapons grade plutonium for nuclear weapons. Nine production reactors and five chemical separation plants were constructed to support this mission. Production of plutonium continued as the principal mission of the Hanford Site until 1989 when the last of the production reactors was shut down. Plutonium was formed in the reactor cores by irradiating uranium fuel elements with low-energy neutrons. The plutonium $\left(\mathrm{Pu}^{239}\right)$ was extracted from the irradiated fuel rods through a series of chemical separation processes.

This chemical separation process resulted in the production of millions of gallons of hazardous and radioactive wastes. The waste included high-level, transuranic, low-level, hazardous, and mixed waste. Subsequent processing of these wastes, including recovery of uranium, cesium and strontium, and the evaporation and resulting concentration of wastes have created mixtures of radioactive materials, including liquids, saltcake, soft sludges, and hardpan. The majority of this waste was transferred to Underground Storage Tanks (UST) for treatment and storage.

The first tanks constructed at the Hanford Site were the SSTs, which were built between 1943 and 1964. The tanks are cylindrical reinforced concrete structures with a single carbon steel liner 
covering the bottom and sides of the tank. The tanks have an unlined concrete dome that covers the top of the tank with above-grade access risers that extend from the tank through the approximately 8 feet of earth that acts as shielding. The SSTs were not constructed with adequate provisions for leak detection, leak prevention, accessibility, and instrumentation. There are 149 SSTs within 12 tank farms located in the 200 Area. The majority (133) of these tanks are 100 series tanks that are 75 feet in diameter with heights ranging from 30 to 54 feet. Forty of these tanks are considered saltcake tanks, 85 are sludge tanks, and 24 tanks are mixed with both sludge and saltcake. Sixty-seven (67) of these tanks have been placed on the list of known or suspected leakers.

In 1968, the Double-Shell Tanks (DSTs) were constructed having a secondary containment shell and more sophisticated leak detection and monitoring equipment. The end of the Cold War brought about a change in the mission of the Hanford Site from plutonium production to environmental restoration. The SSTs, due to design, age and construction limitations, are considered much higher risk to the environment than their DST counterparts. To minimize the risk associated with liquid wastes in the SSTs the interim stabilization (IS) project began in 1980 . IS is removing liquid wastes from the SSTs and transferring the wastes to DSTs, which represent a lower environmental risk. The program first removed all easily pumpable liquids (supernate) from the surface of the tank wastes. The remaining fluids, called interstitial liquid, was trapped within the matrix of the settled salts are being removed by saltwell pumping. The process typically involves placing a pump and filter screen at the bottom of the tank to remove fluid as it drains from the salt matrix.

After transfer to the DST system for safe storage, the waste will be transferred to the Waste Treatment Facility (WTF) where the wastes will be immobilized through vitrification. The current baseline for Phase 1 feed to the WTF includes retrieval and feed of four SSTs; two sludge tanks, C-104 and C-107 and two salt cake tanks, S-102 and S-112. Initiation of waste retrieval is planned for an additional 15 SSTs during Phase 1 to provide DST backfill and to stage waste for Phase 2 vitrification. Thirteen of the SSTs with retrievals planned for DST backfill prior to 2018 are classified as salt cake tanks, while two are sludge tanks. With 15 of the 19 SSTs scheduled as feed or DST backfill during Phase 1 being saltcake tanks, saltcake dissolution may become the primary method of retrieval of SST wastes. The life cycle costs for retrieval of these tanks is currently estimated to exceed a $\$ 1,000$ million dollars. The evaluation and subsequent implementation of retrieval technologies other than PPS, where appropriate, is essential to lower the life cycle costs of SST retrieval.

\subsection{Milestones}

CHG has recently completed TPA milestone negotiations with DOE and the State of Washington Department of Ecology (Ecology) to define commitments and goals associated with near-term SST retrievals. The Saltcake Dissolution Retrieval Demonstration is being planned to fulfill the requirements of Milestone $\mathrm{M}-45-03 \mathrm{C}$, which reads as:

" Complete full-scale saltcake waste retrieval technology demonstration at single-shell tank S112. Waste shall be retrieved to the DST system to the limits of the technology (or technologies) selected. Selected saltcake retrieval technology (or technologies) must seek to improve upon the PPS baseline in the areas of expected retrieval efficiency, leak loss potential, and suitability for use in potentially leaking tanks. This demonstration shall also include the installation of implementation of full-scale leak detection, monitoring, and mitigation (LDMM) technologies. The parties recognize and agree that this action of for demonstration and initial waste retrieval purposes. Completion of this demonstration shall be by written approval of DOE and Ecology. 
Goals of this demonstration shall include the retrieval to safe storage of approximately 550 curies of mobile, long-lived radioisotopes and $99 \%$ of tank contents by volume (per DOE BBI data, 8/01/2000)."

The milestones and target milestones associated with this retrieval are summarized in the following table:

\begin{tabular}{|l|l|c|}
\hline \multicolumn{1}{|c|}{ Milestone } & \multicolumn{1}{|c|}{ Description } & Date \\
\hline M-45-03-T03 & Submit S-112 saltcake waste retrieval F\&Rs document & $12 / 30 / 2001$ \\
\hline M-45-03D & Complete S-112 saltcake waste retrieval system design & $5 / 31 / 2003$ \\
\hline M-45-03E & $\begin{array}{l}\text { Complete S-112 saltcake waste retrieval system } \\
\text { construction }\end{array}$ & $9 / 30 / 2004$ \\
\hline M-45-03C & Complete S-112 saltcake waste retrieval demonstration & $9 / 30 / 2005$ \\
\hline
\end{tabular}

\subsection{SALTCAKE DISSOLUTION OVERVIEW}

The current retrieval strategy places emphasis on retrieval of tanks with larger inventories of contaminants of concern. The contaminants of concern are long-lived radionuclides that are considered mobile with respect to the groundwater contamination pathway. One factor that contributes to a chemical's mobility in this pathway is its solubility in water. By retrieving the soluble wastes to safe storage in the DST system, the residual wastes are less mobile and present a significantly reduced environmental and health risk.

In saltcake dissolution retrieval, the soluble wastes are mobilized by dissolving into solution through the addition of a liquid solvent (e.g., inhibited water) to the tank. The solvent is introduced to the waste, and as the waste is solublized it becomes mobile and travels with the solvent. The solvent containing the dissolved waste is then pumped from the tank. If the distribution of the solvent has sufficient energy, the solvent may also serve to erode insoluble waste constituents and provide the force necessary to mobilize these particles as well.

The effectiveness of this method is dependent on the solubility of the waste in the solvent. The more soluble the waste is, the less solvent that is needed to mobilize it and a lower total volume of waste to be transferred to the DST system. Saltcake chemistry varies widely within the SST system and these differences would need to be accounted for in planning. Some tanks have been pumped of free liquids and may require significant addition of solvent prior to receiving any solublized waste, as the saltcake matrix will adsorb the initial additions of solvent. By tracking additions of solvent and the volume and density of solution removed the amount of liquid in the tank can be monitored.

This demonstration will use the Low Volume Density Gradient (LVDG) method as its retrieval method. This method is commonly referred to as the "sprinkler" method and uses an array of sprinklers to evenly distribute the solvent to the waste. LVDG is different from other dissolution methodologies from an operational standpoint. With the exception of an initial solvent addition, the liquids are removed from the tank at the same rate that the solvent is added. This method represents a lower environmental risk, as the peak volume of liquid in the tank is less than other batch-type methods, allowing potential leaks to be mitigated more quickly.

Currently, the effectiveness of dissolution type retrieval is predicted using the Environmental Simulation Program (ESP) model. With the necessary inputs regarding tank composition (e.g. tank characterization data and analyses), ESP can model a given dissolution campaign and predict 
its effectiveness in mobilizing the waste. This demonstration test will attempt to validate the accuracy of this model.

Saltcake dissolution is perceived to have several potential advantages over other methods of recovering SST waste such as past practice sluicing or a crawler-based retrieval. The primary advantages are a relatively low retrieval cost, ease of deployment, and simplicity of operation. In some cases considerable savings may be realized by utilizing the hardware previously installed for IS (saltwell pumping) to remove the salt solutions. Disadvantages of saltcake dissolution include, potential need for a second retrieval campaign (to address insolubles), generation of additional waste volume, and numerous technical uncertainties. Realizing the advantages of saltcake dissolution retrieval may offer schedule relief to the WFD schedule, as well as, budgetary efficiencies, which will become vital if DOE proceeds with levelized funding of the Tank Waste Remediation System (TWRS).

\subsection{SALTCAKE DISSOLUTION DEPLOYMENT HOT TEST}

\subsection{Mission Statement}

To reduce overall environmental risk associated with continued storage of wastes in the SSTs by cost-effective, technically feasible retrieval of SST waste to the DST system for safe storage.

\subsection{Test Hypothesis}

Retrieval of Hanford wastes contained in SSTs by saltcake dissolution is a viable production retrieval option for selected SST wastes. Saltcake dissolution is a retrieval option that is cost effective, technically feasible, consistent with Stakeholder values, and operable and maintainable by plant forces for production. The LDMM strategy can be implemented within the limits to be established by the RPE process.

\subsection{Test Description}

The saltcake dissolution technology deployment in S-112 is proposed to test the practical limits of the technology. The test is intended to be a full-scale hot test of saltcake dissolution as a retrieval alternative. The test will require the design, procurement, construction, operation and maintenance of the Integrated Waste Retrieval System (IWRS). The IWRS will consist of three major systems: the Waste Retrieval System (WRS), the Waste Transfer System (WTS), and Tank Farms Infrastructure. The WRS consists of all systems and components that are involved in the removal of the waste from the tank. The WTS consists of all piping or other transport media (overland lines or truck loadout) as well as all instrumentation and equipment necessary to monitor and control the transfer. Tank Farms Infrastructure consists of all support systems that are required to support the waste retrieval and continued operation during retrieval such as: ventilation system, pit and riser modifications, utility upgrades, monitoring and control systems.

Factors in determining if saltcake dissolution is a viable production option are:

- Compliance with Environmental Regulations and Hazardous Waste Standards,

- Ability to retrieve the wastes of a given tank in required quantity at required rates,

- Operability and maintainability of the system using plant forces, and

- Design, procurement, construction and retrieval costs and schedule is favorable compared with current planning baseline and Waste Feed Delivery Schedule 
The retrieval will continue until the practical limit of the retrieval technology is reached or the tank is fully retrieved, whichever comes first. What level of retrieval efficiency that the retrieval must fall to before declaring the limit has been reached is yet to be determined. The limit determination will be made by analyzing the cost of continued operation against the risks associated with the remaining waste staying in the tank or being retrieved by other means.

Examples of the types of data that will be collected during the test include, but are not limited to:

- All pertinent cost and schedule data,

- Waste retrieval rates,

- Solvent introduction rates,

- Solvent distribution data,

- Dissolved wastes selected physical composition and characteristics,

- Leak detection and tank monitoring data

- Mass Balance data, and

- General maintenance and operations records.

\subsection{Scope}

This document examines the test objectives of the in tank hot test of the saltcake dissolution retrieval demonstration. Additional testing such as: vendor testing, component tests, on-site verification tests, functional test, required/recommended cold tests and training are not detailed in this document. These tests are recognized to be an integral part in the development of a successful retrieval system, but will be detailed in the saltcake dissolution test and evaluation plan.

This deployment of an alternative retrieval technology applies only to the selected SST, Tank 241-S-112.

Data Quality Objectives for this retrieval will be developed in fiscal year 2001. This document is not intended function as a DQO. Specific needs regarding data quality will be addressed in conceptual engineering.

\subsection{TEST GOALS}

There are a number of technical, programmatic and operational goals for the saltcake dissolution deployment in S-112. The goals represent advantages that can be realized by DOE in terms of environmental risk reduction and technical advancement of the SST retrieval program. The recently renegotiated TPA Milestone, $\mathrm{M}-45-03 \mathrm{C}$, calls out specific production goals for this retrieval demonstration. The milestone goals are stated as:

"Goals of this demonstration shall include the retrieval to safe storage of approximately 550 curies of mobile, long-lived radioisotopes and $99 \%$ of tank contents by volume (per DOE BBI data, 8/01/2000)."

Additional goals of the saltcake demonstration deployment that were developed by evaluation and discussion of SST retrieval program needs are:

- To adapt and mature for the SST environment, saltcake dissolution retrieval technologies as a viable alternative retrieval technology. 
- To improve upon the current baseline retrieval of PPS in the areas of expected retrieval efficiency, leak loss potential, and suitability for use in potentially leaking tanks.

- To demonstrate the ability of plant forces to install, operate, maintain, and decontaminate (for potential reuse) the WRS.

- To develop a solid, tested, defensible planning basis for salt cake tanks scheduled for Phase I WFD and DST backfill.

- To realize efficiencies where possible by utilizing experience, expertise and equipment used by IS.

- To deploy a full-scale LDMM system/strategy that can detect, monitor, and mitigate leaks within the limits established by the RPE process.

- To successfully retrieve a SST for a less than half the current baseline planning estimate for PPS.

- To validate the ESP model as an accurate predictor of saltcake dissolution retrieval activities.

\section{$5.0 \quad$ TEST OBJECTIVES}

There are a number of objectives for the saltcake dissolution deployment in S-112. The test objectives represent activities that need to be completed to prove or disprove the test hypothesis. The objectives were developed by evaluation and discussion of SST retrieval program needs, technical uncertainties and long term planning and funding constraints. The objectives for the saltcake dissolution technology deployment in S-103 are presented by organization, system or function that will be performing the activity or benefit from the test.

The Objectives of the Saltcake Dissolution Retrieval Demonstration Test are:

\subsection{Technical Considerations}

- To collect the appropriate data and perform necessary analyses to resolve or mitigate open technical issues, uncertainties and risks associated with saltcake dissolution, including but not limited to:

- Criticality concerns associated with the preferential retrieval of high solubility constituents.

- Fully saturated solutions may precipitate solids in transfer lines.

- Settlement/collapse of waste may damage in tank hardware.

- Preferential dissolution results in the depletion of corrosion inhibitors.

- Reduction in retrieval efficiency when waste volume gets low.

- Insoluble constituents may concentrate to form an impermeable layer.

- Ventilation systems may not be capable of handling high volumes of water vapor.

- Limited access to tank may result in "shadowing" around in tank hardware.

- Saltcake dissolution produces large volumes of diluted waste.

- Waste may "cling" to in tank hardware to a degree that damages or rips loose the hardware as waste level drops. 
- Water-based retrieval technologies have the potential of spreading contamination in the vadose zone.

- Understanding how the saltcake matrix dissolves with the addition of solvent, including: channeling of solvent as the matrix dissolves and its affect on retrieval rate, the physical movement of solvent through the saltcake,

- A clearer understanding of how solvent distribution affects production retrieval rate and quality of retrieval.

- To collect appropriate data to optimize, for future retrieval considerations, the saltcake dissolution retrieval process in terms of the following:

- Technical understanding,

- Cost and schedule requirements,

- Integration with tanks farms projects and operations (especially interim stabilization activities), and

- Risk to the worker, public and the environment.

- To collect data necessary to validate the accuracy and applicability of the ESP model for saltcake dissolution.

- Determine if IS goals of less that $5 \mathrm{Kgal}$ free liquid and less than $50 \mathrm{Kgal}$ total liquid volume can be met more efficiently with the addition of diluent to the tank. Determine if solutions less saturated than those found during typical IS operations, improve pump operability.

\subsection{Operations and Maintenance Objectives}

- Demonstrate the ability to safely operate and maintain the IWRS in accordance with the AB.

- Demonstrate the ability to recover from predicted upset conditions.

- Deploy the IWRS.

- Demonstrate the ability to decontaminate/remove/reuse the IWRS (where applicable).

\subsection{Retrieval System Objectives}

- Deploy the retrieval system into a SST.

- Demonstrate the retrieval system can handle the harsh radiological and chemical environments in the tanks with commensurate levels of maintenance.

- Demonstrate the ability of the WRS to mobilize and convey SST waste to the WTS.

- Demonstrate the ability to remove the WRS from the tank for maintenance or reuse where appropriate. 
- Collect the data necessary to determine:

- The practical Limit of the Retrieval Technology,

- Appropriate physical characteristics of waste retrieved

- Waste retrieval rates, and

- Waste retrieval efficiencies.

\subsection{LDMM Objectives}

- Deploy a full-scale LDMM technologies and strategy that employs both in-tank and extank to detect and monitor leaks.

- Monitor and control retrieval and transfer operations to mitigate risks to the vadose zone within the limits established by the RPE process.

- Collect data necessary to determine leak potential and environmental risk associated with saltcake dissolution at S-112.

- Demonstrate the ability of operate and maintain the LDMM system.

\subsection{Waste Transfer System Objectives}

- Transfer waste to DST system for safe storage.

- Demonstrate the ability to minimize or prevent precipitation of waste from saturated solutions.

- Demonstrate measures to mitigate or recover from line blockage or other predicted upset conditions.

\subsection{Infrastructure Objectives}

- Demonstrate that plant modifications and necessary infrastructure upgrades can be made to adequately support the waste retrieval system.

\subsection{Cost, Planning and Schedule Objectives}

- To meet the negotiated TPA milestones and target milestones associated with this retrieval demonstration. Those milestones are included in the following table:

\begin{tabular}{|l|l|c|}
\hline \multicolumn{1}{|c|}{ Milestone } & \multicolumn{1}{|c|}{ Description } & Date \\
\hline M-45-03-T03 & Submit S-112 saltcake waste retrieval F\&Rs document & $12 / 30 / 2001$ \\
\hline M-45-03D & Complete S- I12 saltcake waste retrieval system design & $5 / 31 / 2003$ \\
\hline M-45-03E & $\begin{array}{l}\text { Complete S-112 saltcake waste retrieval system } \\
\text { construction }\end{array}$ & $9 / 30 / 2004$ \\
\hline M-45-03C & Complete S-112 saltcake waste retrieval demonstration & $9 / 30 / 2005$ \\
\hline
\end{tabular}

- To collect the necessary technical, financial and programmatic information to establish a strong defensible planning basis and funding profile for saltcake dissolution retrieval of SSTs based on actual data. 
- Collect data required to assess cost and schedule risks associated with saltcake dissolution.

\subsection{ASSUMPTIONS/CONSTRAINTS}

- The SST selected for this demonstration is Tank 241-S-112.

- Tank 241-S-112 is a structurally sound, non-leaking tank. The new retrieval technology will not be demonstrated in a tank that represents a higher risk to the vadose zone at this stage of maturity.

- Adequate access is available to the tank to provide for the IWRS and all additional monitoring equipment required to complete the test.

- Data Quality Objectives for this retrieval will be developed in fiscal year 2001. This document is not intended function as a DQO. Specific needs regarding data quality will be addressed in conceptual engineering.

- Permanent infrastructure upgrades will be kept to a minimum, portable and reusable infrastructure will be used where appropriate.

- The saltcake dissolution retrieval technology demonstration and interim stabilization activities will not negatively impact one another.

- The receiver tank for this retrieval is Tank 241-SY-102.

- The dissolution retrieval technology chosen for this demonstration is the LVDG or "sprinkler" method. Preliminary Engineering is nearly complete for using LVDG in tank 241-S-103, the baseline saltcake dissolution retrieval demonstration tank prior to selection of tank S-112.

\subsection{REFERENCES}

HNF-3554, 1998, Investigation of the Low Volume Density Gradient (LVDG) for Waste Removal in Hanford's Single Shell Storage Tanks, Numatec Hanford Corporation, Richland, Washington.

HNF-5095, 1999, Single-Shell Tank Program Plan, Rev. 0, Lockheed Martin Hanford Corporation, Richland, Washington.

HNF-5193, 1999, Saltcake Dissolution FY 1999 Status Report, Rev. 0, Numatec Hanford Corporation, Richland, Washington.

RPP-6821, 2000, Preferred Technology for S-103 Dissolution Retrieval Demonstration, Rev. A Draft, CH2M Hill Hanford Group, Inc., Richland, Washington.

RPP-6830, 2000, 241-S-103 Saltcake Dissolution Preliminary Engineering Report, Rev. A Draft, $\mathrm{CH} 2 \mathrm{M}$ Hill Hanford Group, Inc., Richland, Washington.

HNF-SD-HTI-MAR-001, 1998, Mission Analysis Report for the Hanford Tanks Initiative, Rev. 1, Lockheed Martin Hanford Corporation, Richland, Washington. 
RPP-5044, 1999, River Protection Project Fiscal Year 2000 Multi-Year Work Plan Summary, Rev. 0, Lockheed Martin Hanford Corporation, Richland, Washington.

Letter, Conclusion Agreement on Negotiation of Requirements Governing the Near Term Retrieval of Wastes from the Department of Energy's Single-Shell Tanks (Negotiations Pursuant to Milestone M-45-00A). 